A N N A L ES

UNIVERSITATIS MARIAE CURIE-SKŁODOWSKA

LUBLIN - POLONIA

VOL. LXIV, 1

SECTIO G

2017

Uniwersytet Marii Curie-Skłodowskiej w Lublinie

hanna.spasowska@poczta.umcs.lublin.pl

\title{
HANNA SPASOWSKA-CZARNY
}

\section{Wywłaszczenie a nowe regulacje Prawa geologicznego i górniczego}

Expropriation and New Rules of Geological and Mining Law

Kompetencja państwa do kształtowania treści prawa własności i praw majątkowych wynika ze „społecznego związania własności” znajdującego oparcie w wiodącej zasadzie polskiego porządku konstytucyjnego dobra wspólnego ${ }^{1}$. Ramy tej kompetencji określa art. 84 Konstytucji RP, który wprost upoważnia do nakładania podatków i danin publicznych ${ }^{2}$, oraz art. 83 Konstytucji RP, który wyraża zasadę monopolu państwa na stosowanie sankcji w interesie poszanowania prawa ${ }^{3}$.

Własność jako prawo człowieka ma charakter uniwersalny ${ }^{4}$. Kwalifikuje się ją w ramach grupy praw tzw. pierwszej generacji, uznawanych za wykazujące ,pewne

1 Ustawa z dnia 2 kwietnia 1997 r. - Konstytucja Rzeczypospolitej Polskiej (Dz.U. nr 78, poz. 483 z późn. zm.), art. 1, dalej jako: Konstytucja RP.

2 Zgodnie $\mathrm{z}$ dominującym w orzecznictwie Trybunału Konstytucyjnego poglądem upoważnienie to ma swoje granice $\mathrm{w}$ ochronie istoty prawa własności i praw majątkowych. Zob. wyroki TK: z dnia 6 stycznia 2009 r., SK 22/06, OTK-A 2009, nr 1, poz. 1; z dnia 30 listopada 2004 r., SK 31/04, OTK-A 2004, nr 10, poz. 110; z dnia 20 listopada 2002 r., K 41/02, OTK-A 2002, nr 6, poz. 83; z dnia 16 kwietnia 2002 r., SK 23/01, OTK-A 2002, nr 3, poz. 26; z dnia 4 maja 2004 r., K 8/03, OTK-A 2004, nr 5, poz. 37; z dnia 30 stycznia 2001 r., K 17/00, OTK 2001, nr 1, poz. 4.

3 W utrwalonym orzecznictwie Trybunału Konstytucyjnego przyjmuje się, że ograniczenia praw majątkowych mające charakter sankcji mogą przekraczać zwykłą miarę proporcjonalności. Zob. przede wszystkim wyrok TK z dnia 12 stycznia 1999 r., P 2/98, OTK 1999, nr 1, poz. 2, a także wyroki TK: z dnia 30 listopada 2004 r., SK 31/04, OTK-A 2004, nr 10, poz. 110; z dnia 18 kwietnia 2000 r., K 23/99, OTK 2000, nr 3, poz. 89; z dnia 26 marca 2002 r., SK 2/01, OTK-A 2002, nr 2, poz. 15.

4 I. Nakielska, Prawo do własności w świetle Europejskiej Konwencji Praw Człowieka, Gdańsk 2002, s. 23; K. Zaradkiewicz, Instytucjonalizacja wolności majątkowej. Koncepcja prawa podstawowego własności i jej urzeczywistnienie w prawie prywatnym, „Studia i Materiały Try- 
cechy praw gospodarczych i socjalnych, ujawnianych zwłaszcza wtedy, gdy własność chroni ekonomiczny interes jednostek" ". Jest ona zaliczana do grupy ekonomicznych praw podstawowych ${ }^{6}$. Poza pozytywnym systemem prawnym własność nie może być traktowana jako prawo podmiotowe. Nie jest prawem „naturalnym”, które ma swoją treść niezależną od systemu prawnego. Jej treść jest zależna od woli prawodawcy i nie może być analizowana w oderwaniu od aktualnego ujęcia normatywnego 7 .

Własność jako konstytucyjne prawo podstawowe nie została zdefiniowana ${ }^{8}$. Jest rozumiana różnie w znaczeniu konstytucyjnym oraz w prawie prywatnym ${ }^{9}$, przede wszystkim jest to tradycyjna instytucja prawa cywilnego. W tym ostatnim ujęciu prawo własności jest prototypem praw „władczych” - bezwzględnym majątkowym prawem podmiotowym. Stanowi ona prawo służące urzeczywistnianiu różnorodnych aktów władztwa osoby nad dobrem majątkowym, a zatem jest prawnym instrumentem przyporządkowania tego dobra ${ }^{10}$. Konstytucja RP posługuje się różnymi terminami: „własność”11, „prawo własności”12 oraz „prawo do własności”" Znaczenie poszczególnych określeń i relacja między nimi nie są jasne ${ }^{14}$.

bunału Konstytucyjnego" 2013, t. 45, s. 52. Powszechna Deklaracja Praw Człowieka, uchwalona przez Zgromadzenie Ogólne ONZ rezolucją 217/III A w dniu 10 grudnia 1948 r. w Paryżu, traktuje własność jako jedno z osobistych praw człowieka, które przysługuje każdemu samodzielnie lub z innymi. Deklaracja nie definiuje pojęcia własności, nie stanowi o wywłaszczeniu, jednak zakazuje arbitralnego pozbawiania tego prawa. Zob. art. 17 Powszechnej Deklaracji Praw Człowieka, www. unic.un.org.pl/prawa_czlowieka/dok_powszechna_deklaracja.php [dostęp: 06.02.2017]. Własność podlega ochronie także w art. 1 Protokołu nr 1 do EKPC z dnia 20 marca 1952 r. (Dz.U. z 1995 r., nr 36, poz. 175 ze zm.). Konwencja o ochronie praw człowieka i podstawowych wolności (w skrócie: Konwencja Europejska lub EKPC) to umowa międzynarodowa z zakresu ochrony praw człowieka zawarta przez państwa członkowskie Rady Europy. Konwencja została otwarta do podpisu 4 listopada 1950 r., a po uzyskaniu niezbędnych 10 ratyfikacji weszła w życie 3 września 1953 r. Wyżej wymieniony przepis gwarantuje osobom fizycznym i prawnym prawo poszanowania mienia, zakazując pozbawienia własności, o ile nie jest dokonywane w interesie publicznym, na warunkach przewidzianych w ustawie oraz zgodnie z ogólnymi zasadami prawa międzynarodowego.

5 Tak np. I. Nakielska, op. cit., s. 26-27.

6 Zob. np. wyrok TK z dnia 18 września 2008 r., K 7/07, OTK-A 2008, nr 7, poz. 123.

7 Nie stanowi w związku z tym kategorii pojęciowej ponadnormatywnej. Tak np. K. Zaradkiewicz, Instytucjonalizacja wolności ..., s. 15 i n. Na temat własności w kontekście wywłaszczenia zob. także: M. Zdyb, Wywtaszczenia. Komentarz. Orzecznictwo, Lublin 1993, s. 24 i n., 177-179; M. Karpiuk, Instytucja wywłaszczenia nieruchomości, Warszawa 2015; M. Szalewska, Wywłaszczenie nieruchomości, Toruń 2005, s. 19-27.

8 Zob. np. B. Banaszak, Prawo konstytucyjne, Warszawa 2010, s. 250.

9 F. Zoll, [w:] Prawo cywilne w zarysie. Prawo rzeczowe, red. F. Zoll, A. Szpunar, t. 2, z. 1, Kraków 1947, s. 26.

${ }_{10}$ K. Zaradkiewicz, Artykut 21, [w:] Konstytucja RP, t. 1: Komentarz do art. 1-86, red. M. Safjan, L. Bosek, Warszawa 2016.

11 Konstytucja RP, art. 20, 21, art. 64 ust. 2 i 3.

12 Konstytucja RP, art. 64 ust. 3, art. 165 ust. 1, art. 233 ust. 3 (odwołujący się do art. 64).

13 Konstytucja RP, art. 64 ust. 1.

14 Tak np. T. Dybowski, Ochrona własności w polskim prawie cywilnym (rei vindicatio - 
Podstawowym celem i funkcją konstytucyjnej własności jest ochrona sfery wolności majątkowej jednostki. Własność konstytucyjna ma zapewniać bezpieczeństwo egzystencji w społeczeństwie, materialny byt i niezależność ${ }^{15}$. Gwarantować ma zatem ekonomiczną wolność jednostki, niezależność w realizacji różnorodnych potrzeb życiowych (autonomia majątkowa). Trybunał Konstytucyjny podkreśla, że:

[...] przesłanką poszanowania [...] godności człowieka jest między innymi istnienie pewnego minimum materialnego, zapewniającego jednostce możliwość samodzielnego funkcjonowania w społeczeństwie oraz stworzenie każdemu człowiekowi szans na pełny rozwój osobowości w otaczającym go środowisku kulturowym i cywilizacyjnym ${ }^{16}$.

W znaczeniu art. 21 Konstytucji RP własność obejmuje w pierwszej kolejności szeroko rozumianą wolność majątkową. W tym sensie jest to wolność podstawowa, której treść obejmuje swobodę dysponowania dobrami majątkowymi. Najogólniej można uznać, że wolność ta „obejmuje możliwość nieskrępowanego, wolnego od państwa, swobodnego kształtowania stosunków majątkowych przez obywateli" ${ }^{17}$. Jednak o wolności majątkowej należy mówić przede wszystkim W znaczeniu jednego z elementów treści prawa podmiotowego - możliwości decydowania o korzystaniu oraz o zadysponowaniu nim w inny sposób określonym dobrem majątkowym (rozrządzeniu, w tym zniszczeniu). Art. 21 Konstytucji RP

actio negatoria), Warszawa 1969, s. 111; L. Garlicki, Artykut 21, [w:] Konstytucja Rzeczpospolitej Polskiej. Komentarz, red. L. Garlicki, t. 3, Warszawa 2003, s. 4; S. Jarosz-Żukowska, Konstytucyjna zasada ochrony własności, Kraków 2003, s. 34, 40. Także Trybunał Konstytucyjny różnie ocenia terminy „własność”, „prawo własności” i „prawo do własności”. Uznaje na przykład, że istnieje jednolite konstytucyjne pojęcie własności (wyrok TK z dnia 21 marca 2000 r., K 14/99, OTK 2000, nr 2, poz. 61); prawo własności w art. 64 Konstytucji RP odpowiada cywilnoprawnemu pojęciu własności (wyrok TK z dnia 25 maja 1999 r., SK 9/98, OTK 1999, nr 4, poz. 78; zob. też wyrok TK: z dnia 12 stycznia 2000 r., P 11/98, OTK 2000, nr 1, poz. 3; z dnia 7 lutego 2001 r., K 27/00, OTK 2001, nr 2, poz. 29); art. 21 ust. 1 Konstytucji RP chroni jedynie prawo własności, ale już nie inne prawa majątkowe (wyrok TK z dnia 12 stycznia 1999 r., P 2/98, OTK 1999, nr 1, poz. 2; postanowienie TK z dnia 17 grudnia 2009 r., U 6/08, OTK-A 2009, nr 11, poz. 178); własność w art. 21 ma charakter autonomiczny i ,wykracza poza ujęcie cywilnoprawne” (wyrok TK z dnia 3 kwietnia 2008 r., K 6/05, OTK-A 2008, nr 3, poz. 41; zob. też np. wyrok TK z dnia 20 kwietnia 2011 r., KP 7/09, OTK-A 2011, nr 3, poz. 26; wyrok TK z dnia 13 grudnia 2012 r., P 12/11, OTK-A 2012, nr 11, poz. 135); własność w znaczeniu konstytucyjnym jest kategorią zbliżoną do ekonomicznego pojmowania własności, a więc będącą synonimem całokształtu praw majątkowych (wyrok TK z dnia 13 grudnia 2012 r., P 12/11, OTK-A 2012, nr 11, poz. 135).

15 Wyrok TK z dnia 10 października 2000 r., P 8/99, OTK 2000, nr 6, poz. 190. Zob. też: wyrok TK z dnia 14 marca 2005 r., K 35/04, OTK-A 2005, nr 3, poz. 23.

16 Wyrok TK z dnia 4 kwietnia 2001 r., K 11/00, OTK 2001, nr 3, poz. 54; wyrok TK z dnia 24 lutego 2010 r., K 6/09, OTK-A 2010, nr 2, poz. 15.

17 C. Banasiński, [w:] Prawo gospodarcze, red. H. Gronkiewicz-Waltz, M. Wierzbowski, Warszawa 2009, s. 77. 
chroni zatem wolność własności (wolności majątkowej), rozumianą jako sfera chroniona $\mathrm{w}$ zakresie dysponowania przedmiotami majątkowymi ${ }^{18}$. Zakazuje bezprawnej ingerencji $\mathrm{w}$ sferę indywidualnego statusu prawnego organom władzy publicznej i wszystkim innym uczestnikom obrotu prawnego. Gwarancja trwałości nie oznacza jednak nienaruszalności prawa majątkowego.

Zdaniem Trybunału Konstytucyjnego własność w znaczeniu cywilnoprawnym stanowi prawo:

[...] o szerokim zakresie, najsilniejszym prawem w stosunku do rzeczy, dającym osobie uprawnionej daleko idące kompetencje, jeśli chodzi o korzystanie z rzeczy, jej używanie, pobieranie pożytków, bezpośrednie lub pośrednie eksploatowanie przedmiotu własności, rozporządzanie nią inter vivos i mortis causa, a nawet wyzbycie się własności wedle własnego upodobania ${ }^{19}$.

Prawo własności, jako podlegające ochronie konstytucyjnej, można określić jako instrument monopolizacji dobra majątkowego, dający bezwzględną moc prawną decydowania o dostępie do tego dobra, umożliwiającą jego wyłączną eksploatację. W wyroku z dnia 24 marca 2003 r. Trybunał Konstytucyjny podkreślił, że:

[...] ustawowe granice treści i wykonywania własności zostały zakreślone w wielu ustawach szczególnych zawierających przepisy zakazujące właścicielom określonego sposobu wykonywania własności lub nakazujące powstrzymanie się od pewnych działań albo zezwalające - pod określonymi warunkami - na całkowite lub częściowe pozbawienie własności ${ }^{20}$.

Podstawowymi elementami treści własności, niezależnie od jej przedmiotu, są: swoboda dysponowania (władztwo, ius disponendi); ograniczona lub mieszcząca się w pewnych granicach pełnia uprawnień; wyłączenie innych osób z możności decydowania o losach poddanego prawu własności przedmiotu majątkowego (ius excludendi) ${ }^{21}$.

Uznając, że własność i jej ochrona nie są wynikiem wyłącznej woli władzy społeczeństwa wobec jednostki, państwa przyjęły na siebie zobowiązanie powstrzymania się od takiego kształtowania własności i jej ochrony, która zniweczy charakter tej własności. W świetle regulacji art. 21 Konstytucji RP należy stwierdzić, iż własność jest prawem dozwolonym na tyle, na ile nie jest konieczne jej ograniczenie lub odebranie dla ochrony interesów społeczeństwa postrzeganych jako interes publiczny. Działania ustawodawcy w wyznaczaniu granic dopuszczalnej ingerencji we własność podlegają ocenie nie tylko z perspektywy kon-

18 K. Zaradkiewicz, Artykut 21; wyrok TK z dnia 13 grudnia 2012 r., P 12/11, OTK-A 2012, nr 11, poz. 135.

19 Wyrok TK z dnia 17 grudnia 2008 r., P 16/08, OTK-A 2008, nr 10, poz. 181.

20 Wyrok TK z dnia 24 marca 2003 r., P 14/01, OTK-A 2003, nr 3, poz. 22.

21 K. Zaradkiewicz, Artykuł 21. 
stytucyjnych standardów, ale także z perspektywy zobowiązań przyjętych przez państwo na mocy aktów prawa międzynarodowego. Ocena tej relacji polega na ustaleniu, czy autonomia władzy ustawodawczej w kształtowaniu treści własności, przypadków ingerencji w tę własność i granic jej ochrony, nie niweczy tej własności jako wartości przynależnej człowiekowi poza wolą ustawodawcy ${ }^{22}$.

Na temat przesłanek dopuszczalności ograniczeń prawa własności wypowiedział się Trybunał Konstytucyjny ${ }^{23}$. Zdaniem Trybunału art. 31 ust. 3 Konstytucji RP ujmuje kumulatywnie przesłanki ograniczeń w korzystaniu z konstytucyjnych praw i wolności ${ }^{24}$. Są to: ustawowa forma ograniczenia, istnienie konieczności wprowadzenia ograniczenia w demokratycznym państwie, funkcjonalny związek ograniczenia $\mathrm{z}$ realizacją wskazanych $\mathrm{w}$ art. 31 ust. 3 wartości (bezpieczeństwo państwa, porządek publiczny, ochrona środowiska, zdrowia i moralności publicznej, wolności i praw innych osób) oraz zakaz naruszania istoty danego prawa i wolności. Analizując przesłankę „konieczności wprowadzenia ograniczenia w demokratycznym państwie", Trybunał Konstytucyjny wyraził pogląd, że jest ona swoistym odpowiednikiem postulatów wynikających z zasady proporcjonalności ${ }^{25}$. Zasada ta:

[...] z jednej strony stawia przed prawodawcą każdorazowo wymóg stwierdzenia rzeczywistej potrzeby dokonania ingerencji $\mathrm{w}$ danym stanie faktycznym w zakres prawa bądź wolności jednostki. Z drugiej zaś winna ona być rozumiana jako wymóg stosowania takich środków prawnych, które będą skuteczne, a więc rzeczywiście służące realizacji zamierzonych przez prawodawcę celów. Ponadto chodzi tu o środki niezbędne, w tym sensie, że chronić one będą określone wartości w sposób bądź w stopniu, który nie mógłby być osiągnięty przy zastosowaniu innych środków. Niezbędność to również skorzystanie ze środków jak najmniej uciążliwych dla podmiotów, których prawa lub wolności ulegną ograniczeniu. Ingerencja w sferę statusu jednostki musi więc pozostawać w racjonalnej i odpowiedniej proporcji do celów, których ochrona uzasadnia dokonane ograniczenie ${ }^{26}$.

Konstrukcja prawna wywłaszczenia była od początku uwarunkowana jej celami. Początkowo miała stanowić podstawowy środek odpłatnego pozyskania przez państwo określonego prawa, jeśli byłoby ono niezbędne do realizacji waż-

22 M. Wolanin, Wywłaszczenie jako prawny instrument powiększania publicznej własności nieruchomości, cz. I, „Nieruchomości” 2009, nr 7.

23 Wyrok TK z dnia 11 maja 1999 r., K 13/98, OTK 1999, nr 4, poz. 74.

24 E. Bagińska, L. Parchomiuk, Konstytucyjne podstawy odpowiedzialności odszkodowawczej z tytułu szkód wyrządzonych zgodnym z prawem działaniem administracji publicznej, [w:] System Prawa Administracyjnego, t. 12: Konstytucja Rzeczypospolitej Polskiej, red. R. Hauser, Warszawa 2010, s. 135.

25 Ibidem.

26 Podobne poglądy są wyrażane w literaturze. Por. K. Wojtyczek, Granice ingerencji ustawodawczej w sfere praw człowieka w Konstytucji RP, Warszawa 1999, s. 139 i n.; idem, Zasada proporcjonalności, [w:] Prawa i wolności obywatelskie w Konstytucji RP, red. B. Banaszak, A. Preisner, Warszawa 2002, s. 670, 682. Podobnie: M. Wyrzykowski, Granice praw i wolności-granice władzy, [w:] Obywatel - jego wolności i prawa, oprac. B. Radzikowska, Warszawa 1998, s. 51. 
nych celów publicznych ${ }^{27}$. Z czasem ta funkcja wywłaszczenia została rozwinięta i uogólniona; zaczęto przyjmować, że wywłaszczenie to jeden $z$ instrumentów służących dążeniu do możliwie harmonijnego godzenia potrzeb ogółu z interesami indywidualnymi. Celem stało się pogodzenie ochrony indywidualnej własności prywatnej (jako podstawowej formy współczesnych stosunków własnościowych) z koniecznością rozwoju społecznego i gospodarczego, który wymaga poświęcenia interesu indywidualnego. Odtąd wywłaszczenie polega na możliwości pozbawienia uprawnionych $\mathrm{w}$ interesie ogólnym własności lub innego prawa ${ }^{28}$.

Stosownie do zmian funkcji wywłaszczenia zmieniało się też jego pojęcie i konstrukcja. Zmiany sposobu pojmowania terminu wywłaszczenia wiązały się ściśle z kształtowaniem i rozwojem idei ochrony własności. W toku ewolucji rozwiązań prawnych i poglądów doktryny pojawiły się dwie koncepcje określające konstrukcję prawną wywłaszczenia. Pierwszą historycznie jest tzw. klasyczna teoria wywłaszczenia, której źródła są związane z koncepcją własności nienaruszalnej, absolutnej, będącej wynikiem idei rewolucji francuskiej. Akty prawne ówczesnego okresu uznawały wywłaszczenie za jedyną dopuszczalną ingerencję w prawo własności i to tylko wyjątkowo, ze względu na szczególne wymogi interesu publicznego. Zgodnie z klasyczną teorią wywłaszczenie obejmowało tylko pozbawienie własności nieruchomości oraz ewentualnie łączących się z nią praw rzeczowych na nieruchomościach. Taki zakres przedmiotowy instytucji wywłaszczenia odpowiadał ówczesnym warunkom i potrzebom państwa - praktyczne znaczenie dla realizacji celów uzasadniających wywłaszczenie mogły mieć tylko nieruchomości, w przypadku których brak zgody właściciela mógł uniemożliwić realizację celu publicznego. Inaczej było w przypadku własności rzeczy ruchomych, które były (i są) szeroko dostępne i praktycznie zawsze istnieje możliwość ich nabycia, wytworzenia lub zastąpienia innymi, jeżeli są potrzebne dla realizacji celu publicznego ${ }^{29}$. Wraz z upływem czasu ukształtowała się druga, obok klasycznej, teoria wywłaszczenia - tzw. materialna (szeroka). W najszerszym znaczeniu wywłaszczenie należy rozumieć jako odebranie przez państwo praw podmiotowych w indywidualnym przypadku za odszkodowaniem. W przypadku szerokiej konstrukcji wywłaszczenia przedmiotem ingerencji może być każde indywidualne prawo podmiotowe, zarówno o charakterze prywatno-, jak i publicznoprawnym, przy czym w przypadku praw bezwzględnych (zwłaszcza prawa własności) ingerencja może polegać nie tylko na odebraniu, ale i na indywidualnym ograniczeniu prawa ${ }^{30}$.

27 T. Woś, Wywłaszczanie nieruchomości i ich zwrot, Warszawa 2011, s. 21.

28 S. Czuba, Cywilnoprawna problematyka wywtaszczenia, Warszawa 1980, s. 5, cyt. za: E. Bagińska, L. Parchomiuk, op. cit., s. 139. Podstawowe wyznaczniki wywłaszczenia wymienia M. Zdyb, Wywłaszczenia ..., s. 181-182.

29 Por. M. Zdyb, Wywłaszczenia..., s. 18-19. Zob. także: T. Woś, op. cit., s. 24.

30 E. Bagińska, L. Parchomiuk, op. cit., s. 140. 
Uogólniając, wywłaszczenie nieruchomości jest instytucją prawną, której istnienie umożliwia państwu pozyskiwanie praw przysługujących do nieruchomości innym podmiotom, jeżeli jest to konieczne dla wykonania istotnych celów publicznych. Aktem prawnym regulującym instytucję zarówno wywłaszczenia, jak i zwrotu wywłaszczonych nieruchomości jest ustawa z dnia 21 sierpnia $1997 \mathrm{r}$. o gospodarce nieruchomościami ${ }^{31}$, od czasu wejścia w życie wielokrotnie nowelizowana. Oprócz u.g.n. ustawodawca przewidział inne regulacje przewidujące wywłaszczenie. Należy w tym miejscu wymienić np. ustawę o szczególnych zasadach przygotowania i realizacji inwestycji w zakresie dróg publicznych ${ }^{32}$, Prawo lotnicze ${ }^{33}$, Prawo geodezyjne i kartograficzne ${ }^{34}$, ustawę o ochronie zabytków i opiece nad zabytkami ${ }^{35}$, ustawę o transporcie kolejowym ${ }^{36}$.

Konstytucja RP nie określa definicji, mechanizmów ani zakresu wywłaszczenia. Analizowane pojęcie wyjaśnił Trybunał Konstytucyjny, który wskazał, że:

[...] wywłaszczenie jest wyjątkową, szczególną formą ingerencji w sferę własności, dopuszczalną w wypadkach, gdy w grę wchodzi cel publiczny. Łączy się ono z ograniczeniem bądź odjęciem w całości prawa własności w drodze aktu indywidualnego, dotyczącego konkretnej nieruchomości, na rzecz konkretnego podmiotu. Polega ono na nabyciu przez państwo własności nieruchomości lub innego prawa do nieruchomości, będącej własnością podmiotu niepaństwowego, w drodze ściśle sformalizowanego postępowania administracyjnego ${ }^{37}$.

Art. 112 ust. 2 u.g.n. definiuje wywłaszczenie jako pozbawienie albo ograniczenie, w drodze decyzji, prawa własności, prawa użytkowania wieczystego lub innego prawa rzeczowego na nieruchomości (tj. użytkowania, służebności,

31 Ustawa z dnia 21 sierpnia 1997 r. o gospodarce nieruchomościami (Dz.U. z 2010 r., nr 102, poz. 651 ze zm.), dalej jako: u.g.n.

32 Ustawa z dnia 10 kwietnia 2003 r. o szczególnych zasadach przygotowania i realizacji inwestycji w zakresie dróg publicznych (Dz.U. nr 80, poz. 721 ze zm.). Ustawa dopuszcza możliwość wywłaszczania nieruchomości dla realizacji inwestycji drogowej. Art. 23 nakazuje w sprawach nieuregulowanych rozdziałem 3 odpowiednio stosować u.g.n.

33 Ustawa z dnia 3 lipca 2002 r. - Prawo lotnicze (Dz.U. z 2002 r., nr 130, poz. 1112) przewiduje możliwość wywłaszczenia nieruchomości, gdy jest to niezbędne do zakładania oraz utrzymania lotniczych urządzeń naziemnych (art. 86 ust. 2-5).

34 Ustawa z dnia 17 maja 1989 r. - Prawo geodezyjne i kartograficzne (Dz.U. z 1999 r., nr 30, poz. 163) stanowi, iż na nieruchomości gruntowej można wydzielić obszar, który jest niezbędny dla ochrony znaku geodezyjnego, magnetycznego, grawimetrycznego i budowli triangulacyjnej. Wydzielenie tych miejsc następuje za zapłatą odszkodowania (art. 15 ust. 2 i 3 ).

35 Ustawa z dnia 23 lipca 2003 r. o ochronie zabytków (Dz.U. z 2003 r., nr 162, poz. 1568). Art. 50 wskazuje, że przesłanką wywłaszczenia jest zaistnienie nieusuwalnego zagrożenia zniszczenia bądź uszkodzenia zabytku wpisanego do rejestru.

36 Ustawa z dnia 28 marca 2003 r. o transporcie kolejowym (Dz.U. z 2003 r., nr 86, poz. 789). Art. 56 przewiduje wywłaszczenie nieruchomości, które polega na przymusowym usunięciu z nieruchomości drzew bądź krzewów.

37 Wyrok TK z dnia 9 grudnia 2008 r., K 61/07, OTK-A 2008, nr 10, poz. 174. 
własnościowego spółdzielczego prawa do lokalu mieszkalnego, spółdzielczego prawa do lokalu użytkowego oraz prawa do domu jednorodzinnego w spółdzielni mieszkaniowej). Konstytucyjne ujęcie wywłaszczenia jest jednak szersze niż powyższe, wielokrotnie wskazywał na to Trybunał Konstytucyjny. Przykładowo w wyroku z dnia 14 marca 2000 r. $^{38}$ Trybunał zaznaczył, że:

[...] przy wykładni pojęć konstytucyjnych nie mogą mieć znaczenia wiążącego i przesądzającego o sposobie ich interpretacji definicje formułowane w aktach niższego rzędu. [...] proces interpretacji pojęć konstytucyjnych powinien przebiegać w odwrotnym kierunku, tzn. to przepisy konstytucyjne winny narzucać sposób i kierunek wykładni postanowień zawartych w innych aktach normatywnych. [...] Termin ten został [...] funkcjonalnie powiązany z przesłankami celu publicznego oraz słusznego odszkodowania, należnego właścicielowi. Zatem realizacja celu publicznego oraz zagwarantowanie słusznego odszkodowania stanowią niezbędne przesłanki konstytucyjnej dopuszczalności każdego wywłaszczenia.

Trybunał Konstytucyjny przyjął wobec tego założenie, że pojęcie „wywłaszczenie" winno być rozumiane szeroko jako „wszelkie pozbawienie własności [...] bez względu na formę" ${ }^{\text {", }}$, a wobec tego wychodzi swoim zakresem poza ramy wyznaczone konstrukcją ukształtowaną na gruncie przepisów u.g.n. ${ }^{40}$

Wywłaszczenie jest jednostronną, publicznoprawną, władczą ingerencją państwa w prawa rzeczowe jednostki w interesie publicznym ${ }^{41}$. Podstawową przesłankę wywłaszczenia określa art. 21 ust. 2 Konstytucji. Zgodnie z tym przepisem wywłaszczenie jest dopuszczalne jedynie wówczas, gdy jest dokonywane na cele publiczne ${ }^{42}$ i za słusznym odszkodowaniem. Odszkodowanie powinno być słuszne, co oznacza, że powinno stanowić ekwiwalent wartości wywłaszczonej nieruchomości ${ }^{43}$.

38 Wyrok TK z dnia 14 marca 2000 r., P 5/99, OTK 2000, nr 2, poz. 60.

39 Por. B. Banaszak, op. cit., s. 196.

40 M. Wolanin, op. cit.

${ }^{41}$ Uchwała NSA z dnia 20 maja 2010 r., I OPS 14/09, ONSAiWSA 2010, nr 4, poz. 55. Więcej o definicji wywłaszczenia zob. np. A. Hetko, Dekret warszawski-wybrane zagadnienia systemowe, Warszawa 2012, s. 3-10; M. Szalewska, op. cit., s. 32; S. Jarosz-Żukowska, Konstytucyjna zasada ochrony..., s. 239.

${ }^{42} \mathrm{Z}$ orzecznictwa wynika, że za cel publiczny sądy uznają „wyłącznie to, co służy ogółowi, jest powszechnie dostępne czy też stanowi dobro całego społeczeństwa lub społeczności regionalnej". Zob. wyrok TK z dnia 16 czerwca 2015 r., K 25/12, OTK-A 2015, nr 6, poz. 82. W wyroku z dnia 17 grudnia 2008 r. (P 16/08, OTK-A 2008, nr 10, poz. 181) TK podkreślił, iż „dla uznania, że realizowany cel jest celem publicznym, decydujące znaczenie ma charakter samego zamierzenia, a nie forma prawna podmiotu, który go realizuje”. Niedopuszczalne jest wywłaszczenie na rzecz podmiotów prywatnych, dla korzyści w postaci interesu prywatnego.

43 Wyrok TK z dnia 19 marca 1990 r., K 2/90, OTK 1990, nr 1, poz. 3. TK stwierdza także, że ,wywłaszczenie jest z natury rzeczy ingerencją w istotę prawa własności, bo oznacza całkowite pozbawienie tego prawa, dlatego wywłaszczenie znajdować musi odrębną podstawę konstytucyjną i dopuszczalne jest tylko za słusznym odszkodowaniem". Tak: wyrok TK z dnia 25 maja 1999 r., SK 9/98, OTK 1999, nr 4, poz. 78. Podobnie: wyrok TK z dnia 17 grudnia 2008 r., P 16/08, OTK-A 2008, nr 10, poz. 181. Z Konstytucji RP nie można wywodzić wprost (bezpośrednio) roszcze- 
Interpretacja pojęcia celu publicznego jako przesłanki wywłaszczenia powoduje trudności wynikające z konfliktu pomiędzy nieokreślonością i zmiennością jako immanentną cechą interesu (celu) publicznego a wymaganiami stabilności i precyzji stawianymi wszystkim przesłankom władczej ingerencji w prawa jednostki. Z jednej strony praktycznie niemożliwe jest stworzenie stałej i jednolitej definicji tego pojęcia. Wynika to z faktu, że interes publiczny jako element wyrażający aktualnie cenne i istotne wartości ogólnospołeczne musi z konieczności podlegać ciągłym zmianom i redefinicjom wraz ze zmianami w zakresie hierarchii owych wartości ${ }^{44}$. Z drugiej strony pojęcie celu publicznego wyznacza zakres dopuszczalności wywłaszczenia, a każda władcza ingerencja w sferę prawną jednostki powinna mieć ściśle określone granice i przesłanki dopuszczalności, aby nie prowadziła do nadużywania władzy ${ }^{45}$.

Przedmiotem sporów w doktrynie i judykaturze jest również kwestia formy wywłaszczenia ${ }^{46}$. Ścierają się tu dwa stanowiska: z jednej strony - idące konsekwentnie za linią szerokiej interpretacji terminu ,wywłaszczenie” i obejmujące nim również pozbawienie prawa bezpośrednio na podstawie ustawy, z drugiej - ograniczające pojęcie wywłaszczenia w zakresie formy tylko do aktów indywidualnych ${ }^{47}$. Przeważające wydaje się być stanowisko drugie. Uzasadniając je,

nia odszkodowawczego. Tak: T. Woś, op. cit., s. 275, 278, 299; L. Bosek, Konstytucyjna formuła odpowiedzialności odszkodowawczej administracji publicznej, [w:] System Prawa Administracyjnego, t. 2: Konstytucyjne podstawy funkcjonowania administracji publicznej, red. R. Hauser, Z. Niewiadomski, A. Wróbel, Warszawa 2012, s. 581. Funkcja gwarancji wartości i jej subsydiarny charakter determinuje wartość odszkodowania, która powinna stanowić ekwiwalent dobra wywłaszczonego. Standard i zakres obowiązku kompensacyjnego wyznacza art. 21 ust. 2 Konstytucji RP. Obowiązek odszkodowawczy w świetle tego przepisu powstaje ex lege. Tak: K. Zaradkiewicz, Artykuł 21. W doktrynie podnosi się problem nieprecyzyjności przesłanki „za słusznym odszkodowaniem”, wskazując, iż jest ono pojęciem nieostrym. Zob. M. Gonet, Wywłaszczanie nieruchomości w rozumieniu ustawy o gospodarce nieruchomościami, „Nieruchomości” 2012, nr 12, s. 15. A contrario, w wyroku z dnia 28 maja 1991 r., K 1/91, TK wyraził pogląd, iż ograniczenia wyznaczające treść i zakres ochrony prawa własności ze względu na swoją istotę, cel i sens społeczny nie zawsze wymagają kompensacji i w rzeczywistości nie zawsze są kompensowane w postaci odszkodowania na rzecz właścicieli rzeczy dotkniętych tymi ograniczeniami. Ponadto u.g.n. dopuszcza możliwość, zamiast odszkodowania pieniężnego, przyznania właścicielowi bądź użytkownikowi wieczystemu wywłaszczonej nieruchomości, za jego zgodą, odpowiedniej nieruchomości zamiennej. Nieruchomość zamienna przyznawana jest z zasobu nieruchomości Skarbu Państwa bądź z zasobu nieruchomości odpowiedniej jednostki samorządu terytorialnego w zależności od tego, na czyją rzecz dokonywane jest wywłaszczenie. Przeniesienie praw do takiej nieruchomości następuje z dniem, w którym decyzja o wywłaszczeniu stała się ostateczna. Decyzja ta stanowi podstawę do dokonania wpisu w księdze wieczystej. Tak: M. Gonet, op. cit., s. 18.

${ }_{4}$ P.J. Suwaj, Konflikt interesów w administracji publicznej, Warszawa 2009, s. 28-29; T. Woś, op. cit., s. 54 i n.; M. Wyrzykowski, op. cit., s. 45.

45 E. Bagińska, J. Parchomiuk, op. cit., s. 150.

46 Ibidem, s. 147.

47 Pierwsze stanowisko popiera m.in. L. Garlicki (op. cit., s. 13-14) oraz TK (w wyroku z dnia 14 marca 2000 r., P 5/99, OTK 2000, nr 2, poz. 60). Zwolennikami drugiego poglądu są m.in.: 
zwraca się uwagę, że na gruncie prawa polskiego tradycyjnie za jedną z cech konstytutywnych konstrukcji prawnej wywłaszczenia uznawano indywidualną postać aktu wywłaszczającego. Pogląd taki prezentowali nie tylko zwolennicy wąskiej, klasycznej teorii wywłaszczenia, ale także przedstawiciele koncepcji szerokiej. Argumentem za wąskim ujmowaniem konstytucyjnego pojęcia wywłaszczenia w odniesieniu do formy tej ingerencji może być też okoliczność, że dzięki temu bardziej przejrzysta stałaby się granica pomiędzy wywłaszczeniem a ograniczeniami ustalającymi treść i zakres ochrony prawa własności ${ }^{48}$. Odmienny pogląd co do formy prezentowany jest w niemieckich teoriach wywłaszczenia ${ }^{49}$.

Reasumując, wywłaszczenie nieruchomości polega na pozbawieniu albo ograniczeniu, w drodze decyzji, prawa własności, prawa użytkowania wieczystego lub innego prawa rzeczowego na nieruchomości. Przedmiot wywłaszczenia może stanowić każde ustawowo stworzone i kształtujące indywidualny status prawny prawo majątkowe, publiczne lub prywatne (własność, ograniczone prawa rzeczowe, wierzytelności, prawa autorskie, patenty, prawa ochronne, poszczególne uprawnienia, np. roszczenia itd. $)^{50}$. Wywłaszczenie nieruchomości może być dokonane, jeżeli cele publiczne nie mogą być zrealizowane w inny sposób niż przez pozbawienie albo ograniczenie praw do nieruchomości, a prawa te nie mogą być nabyte w drodze umowy.

Nowa ustawa z dnia 9 czerwca 2011 r. - Prawo geologiczne i górnicze ${ }^{51}$ weszła w życie 1 stycznia 2012 r. Tym samym utraciła moc poprzednia regulacja - ustawa z dnia 4 lutego 1994 r. - Prawo geologiczne i górnicze ${ }^{52}$. Wprowadzone nową regulacją zmiany dotyczą m.in. problemów specyficznych dla prowadzenia działalności gospodarczej w górnictwie oraz szczególnej sytuacji prawnej nie-

S. Jarosz-Żukowska, Konstytucyjna zasada ochrony..., s. 237 i n.; eadem, Spory wokót pojęcia wywłaszczenia w ujęciu Konstytucji RP, „Państwo i Prawo” 2001, z. 1, s. 22 i n.; wyrok WSA w Warszawie z dnia 12 maja 2005 r., I SA 2250/03, niepubl.

48 Przyjęcie poglądu, iż konstytucyjne pojęcie wywłaszczenia ogranicza się tylko do ingerencji $\mathrm{w}$ formie aktu indywidualnego, pozwala na odróżnienie tego pojęcia od pojęć nacjonalizacji (a także innych, nieokreślanych tym terminem przypadków przejęcia własności na rzecz państwa bezpośrednio na podstawie ustawy) oraz komunalizacji, mających ugruntowane znaczenie w doktrynie i orzecznictwie, choć niewystępujących na gruncie Konstytucji. Por. szerzej: J. Parchomiuk, Odpowiedzialność odszkodowawcza za legalne działania administracji publicznej, Warszawa 2007, s. 156-157.

49 Podobnie: S. Jarosz-Żukowska, Spory wokót pojęcia wywłaszczenia ..., s. 24.

50 Podobnie: M. Zimmermann, Polskie prawo wywłaszczeniowe, Lwów 1939, s. 5; J. Panejko, [w:] Polskie prawo administracyjne w zarysie, red. K.W. Kumaniecki, B. Wasiutyński, J. Panejko, Kraków 1930, s. 905. Zakres art. 112 ust. 2 u.g.n., dotyczący ograniczonych praw rzeczowych na nieruchomości, nie obejmuje hipoteki oraz zastawu, które nie mogą być przedmiotem wywłaszczenia. Tak: wyrok WSA w Warszawie z dnia 9 stycznia 2008 r., I SA/Wa 840/2007, LEX nr 459779.

51 Dz.U. z 2011 r., nr 163, poz. 981, dalej jako: p.g.g.

52 T.j. Dz.U. z 2005 r., nr 228, poz. 1947 ze zm. 
ruchomości położonych na obszarach poszukiwania ${ }^{53}$ i rozpoznawania ${ }^{54}$ kopalin oraz obszarach $^{55}$ i terenach ${ }^{56}$ górniczych, a także ich właścicieli ${ }^{57}$.

Zagadnienia z zakresu stosunków własnościowych, których dotyczą zmiany, to przede wszystkim: wyznaczanie obszarów poszukiwania i rozpoznawania kopalin oraz obszarów i terenów górniczych w kontekście planowania i zagospodarowania przestrzennego; stosunki własnościowe; odpowiedzialność za szkody górnicze oraz wywłaszczenia na obszarach górniczych. Trzeba mieć na uwadze, że te zmiany mogą wkrótce zyskać na znaczeniu ze względu na perspektywy rozwoju sektora wydobycia (np. bursztynu, a w dalszej perspektywie innych kopalin). Już samo wytyczenie obszarów poszukiwania i rozpoznawania kopalin zmienia sytuację prawną nieruchomości znajdujących się w ich granicach. Poszukiwanie i faktyczne rozpoznanie złoża będzie skutkowało przystąpieniem do fazy wydobycia, a to z kolei będzie oznaczało pojawienie się znacznej liczby terenów górniczych, na obszarach których problem działalności górniczej do tej pory nie występował ${ }^{58}$. W rezultacie zakres terytorialny szczególnego reżimu prawnego obowiązującego na obszarach i terenach górniczych oraz liczba właścicieli nieruchomości położonych na tych obszarach powiększy się w sposób znaczący ${ }^{59}$.

53 Poszukiwanie to wykonywanie prac geologicznych w celu ustalenia i wstępnego udokumentowania złoża kopaliny albo wód podziemnych (art. 6 ust. 1 pkt 7 p.g.g.).

54 Rozpoznawanie to wykonywanie prac geologicznych na obszarze wstępnie udokumentowanego złoża kopaliny albo wód podziemnych (art. 6 ust. 1 pkt 17 p.g.g.).

55 Obszar górniczy to przestrzeń, w granicach której przedsiębiorca jest uprawniony do wydobywania kopaliny oraz prowadzenia robót górniczych niezbędnych do wykonywania koncesji (art. 6 ust. 1 pkt 5 p.g.g.).

56 Teren górniczy to przestrzeń objęta przewidywanymi szkodliwymi wpływami robót górniczych zakładu górniczego (art. 6 ust. 1 pkt 15 p.g.g.).

57 Większość uwag przedstawionych poniżej analogicznie odnosi się do właścicieli lokali oraz użytkowników wieczystych, a w pewnym stopniu również do posiadaczy samoistnych oraz zależnych nieruchomości.

58 Granice poszukiwania i rozpoznawania kopalin wyznaczone są w koncesjach na prowadzenie takiej działalności (art. 31 p.g.g.); granice obszarów i terenów górniczych są wyznaczane w treści koncesji na wydobycie kopalin ze złoża (art. 32 ust. 1 p.g.g.).

59 J. Górski, Nowe Prawo geologiczne i górnicze a sytuacja prawna nieruchomości, „Nieruchomości” 2012, nr 7, s. 10. S. Dziubicki wskazuje, że przyczyną wprowadzenia nowej regulacji było pojawienie się informacji o obecności na terytorium Rzeczypospolitej Polskiej pokładów węglowodorów z formacji łupkowych. W efekcie pojawiła się potrzeba zapewnienia inwestorom możliwości szybkiego i bezproblemowego rozpoczęcia działalności wydobywczej. Celem nowych regulacji była likwidacja możliwych barier dla inwestorów ze strony właścicieli nieruchomości, na których miała być prowadzona działalność wydobywcza. Zob. S. Dziubicki, Czy Polaków czekaja wywłaszczenia? Prawo geologiczne i górnicze a prawo użytkowania gruntu, http://infolupki.pgi. gov.pl/pl/prawo-koncesje/czy-polakow-czekaja-wywlaszczenia-prawo-geologiczne-gornicze-prawo-do-uzytkowania [dostęp: 06.02.2017]. 
Zgodnie z art. 10 p.g.g. złoża węglowodorów, węgla kamiennego, metanu występującego jako kopalina towarzysząca, węgla brunatnego, rud metali z wyjątkiem darniowych rud żelaza, metali w stanie rodzimym, rud pierwiastków promieniotwórczych, siarki rodzimej, soli kamiennej, soli potasowej, soli potasowomagnezowej, gipsu i anhydrytu, kamieni szlachetnych, bez względu na miejsce ich występowania, a także złoża wód leczniczych, wód termalnych i solanek są objęte własnością górniczą, która przysługuje Skarbowi Państwa, podczas gdy złoża innych kopalin są objęte prawem własności nieruchomości gruntowej. Wyliczenie to ma charakter wyczerpujący, zamknięty, a więc żadne inne kopaliny poza wymienionymi powyżej nie są objęte przysługującą Skarbowi Państwa własnością górniczą (art. 10 ust. 5 p.g.g.).

Art. 125 u.g.n. pozwala na ograniczenie sposobu korzystania z nieruchomości w celach związanych z poszukiwaniem, rozpoznawaniem i wydobywaniem kopalin stanowiących własność górniczą. Normuje on właściwość organu i formę rozstrzygnięcia, wskazuje podmiot, na rzecz którego ograniczenie może nastąpić oraz przewiduje roszczenie o wykup nieruchomości (w tym przesłanki jego powstania i tryb jego przymusowego dochodzenia). Nakazuje również odpowiednie stosowanie art. 124 u.g.n. w zakresie trybu wszczęcia postępowania, przeprowadzenia rokowań oraz obowiązku przywrócenia nieruchomości do stanu poprzedniego. Przepisy u.g.n. przewidują wywłaszczanie nieruchomości przeznaczonych na inwestycje celu publicznego bądź udzielanie bonifikat (art. 68 ust. 1 pkt 1 u.g.n.), jednak regulacje te mają mniejsze znaczenie niż wykup, o którym mowa w art. 19 p.g.g. choćby z tej przyczyny, że wywłaszczenie w trybie art. 112 i n. u.g.n. może nastąpić wyłącznie na rzecz Skarbu Państwa lub jednostki samorządu terytorialnego (art. 113 ust. 1 u.g.n.), zaś art 19 p.g.g. pozwala na wykupienie nieruchomości przez przedsiębiorcę, a ściślej podmiot, który dysponuje koncesją na działalność określoną w art. 19 ust. 1 p.g.g. ${ }^{60}$

Rozwiązanie prawne umożliwiające przedsiębiorcom przymusowy wykup nieruchomości może wydawać się wątpliwe z konstytucyjnego punktu widzenia. Wywłaszczenie, będąc instytucją prawa publicznego, jest narzędziem umożliwiającym ingerencję $\mathrm{w}$ cudze prawo własności przez jego ograniczenie lub pozbawienie. Stanowi ono istotną funkcję dla prawidłowej realizacji zadań publicznych, które nierzadko są możliwe do wykonania jedynie przez władcze działanie państwa. $Z$ tego powodu jedynie cele publiczne mogą być elementem niezbędnym dla dopuszczalności wywłaszczenia. Specyfika instrumentów prawnych pozwalających na pozbawianie prawa lub ograniczanie prawa własności nieruchomości gruntowych na potrzeby poszukiwania i rozpoznawania oraz wydobywania kopalin polega na tym, że takie de facto wywłaszczenie następuje na rzecz przedsię-

${ }^{60}$ H. Schwarz, Prawo geologiczne i górnicze. Komentarz, t. 1, Wrocław 2012, s. 163. 
biorców prywatnych ${ }^{61}$. Pojawia się pytanie, na ile działalność gospodarczą, polegającą na wydobyciu kopalin, można uznać za cel publiczny.

$\mathrm{Z}$ jednej strony wydaje się, że prowadzenie tego typu działań mieści się w kategorii zwykłej działalności gospodarczej i nieuprawnione jest uprzywilejowanie takich podmiotów, jak przedsiębiorstwa poszukiwawcze i wydobywcze, nadając im prawo do wywłaszczania. $Z$ drugiej strony należy pamiętać, że przedsiębiorca prowadzący wydobycie kopalin ze złóż korzysta z prawa użytkowania górniczego. Nie jest właścicielem kopalin, korzysta jedynie z własności należącej do Skarbu Państwa. Wątpliwości rozwiewa art. 6 u.g.n. pkt 8 - poszukiwanie i rozpoznawanie oraz wydobywanie kopalin będących własnością Skarbu Państwa i będących przedmiotem własności górniczej należy do katalogu celów publicznych dopuszczających wywłaszczenie, co wydaje się być uzasadnione ważnym interesem publicznym i potrzebami gospodarczymi państwa ${ }^{62}$. W konsekwencji wywłaszczenie jest więc możliwe na rzecz podmiotu prywatnego, jednak dla realizacji celu publicznego ${ }^{63}$.

Poprzednie rozwiązania legislacyjne dawały wyłącznie możliwość ograniczenia, a nie pozbawienia prawa własności. Na płaszczyźnie cywilnoprawnej przedsiębiorcom przysługiwało roszczenie o czasowe ograniczenie własności całości lub części nieruchomości potrzebnych na prowadzenie takiej działalności (za wynagrodzeniem). Prawo żądania wykupu przysługiwało co do całości lub części nieruchomości wyłącznie ich właścicielom, jeżeli ograniczenia własności skutkowały niemożliwością korzystania z nieruchomości w dotychczasowy sposób. Na płaszczyźnie administracyjno-prawnej przedsiębiorcy prowadzący prace polegające na poszukiwaniu i rozpoznawaniu oraz wydobywaniu kopalin będących przedmiotem własności Skarbu Państwa oraz węgla brunatnego mieli prawo wnioskować do właściwego starosty o czasowe, lecz nieprzekraczające roku, ograniczenie (za odszkodowaniem) korzystania przez właścicieli z ich nieruchomości lub ich części, bez możliwości żądania przez tych właścicieli, aby przedsiębiorcy dokonali wykupu tych nieruchomości. Wzajemna relacja obu regulacji nie jest jasna, a w piśmiennictwie, już od czasu wejścia w życie ustawy o gospodarce nieruchomościami w 1998 r., dostrzegano wyjątkowy brak synchronizacji pomiędzy przewidzianym $\mathrm{w}$ tej ustawie uprawnieniem administracyjnym a zapisami prawa geologicznego i górniczego ${ }^{64}$.

${ }_{61}$ P. Połczyński, Ograniczenie korzystania z nieruchomości poprzez zezwolenie na poszukiwanie lub wydobywanie kopalin. Komentarz do art. 125 ustawy o gospodarce nieruchomościami, Legalis; S. Dziubicki op. cit.

${ }_{62}$ P. Połczyński, op. cit.

${ }_{63}$ K. Zaradkiewicz, Artykut 21.

64 R. Mikosz, Stosunek ustawy o gospodarce nieruchomościami do prawa geologicznego i górniczego (zagadnienia wybrane), „Rejent” 1998, nr 12, s. 105-121. 
Obecna regulacja p.g.g. nie rozwiała tych wątpliwości. W przypadku roszczenia cywilnoprawnego przysługującego przedsiębiorcom wprowadzono dodatkowe zastrzeżenie, że korzystanie przez przedsiębiorcę z cudzej nieruchomości nie może polegać na pobieraniu pożytków ${ }^{65}$. Natomiast w przypadku roszczenia administracyjno-prawnego maksymalny okres ograniczenia prawa własności wydłużono z roku do okresu, na jaki została udzielona koncesja oraz przyznano właścicielom prawo żądania wykupu nieruchomości lub ich części, jeżeli nie mogą w sposób prawidłowy z nich korzystać oraz zawsze, jeżeli czas, na jaki ustanowiono ograniczenie, przekracza rok, niezależnie od jego uciążliwości (art. 125 ust. 3 u.g.n.). Zdecydowanie najistotniejsza zmiana polega na przyznaniu przedsiębiorcom, posiadającym koncesję na wydobywanie węglowodorów, węgla kamiennego i węgla brunatnego oraz na podziemne bezzbiornikowe magazynowanie węglowodorów, prawa wykupu nieruchomości położonych na terenie obszaru górniczego w zakresie niezbędnym do wykonywania działalności określonej w koncesji (art. 19 p.g.g.). Takie rozwiązanie jest w założeniu ułatwieniem dla przedsiębiorców i niekoniecznie musi być oceniane jako pogorszenie pozycji właścicieli nieruchomości gruntowych ${ }^{66}$.

W przypadku braku woli umownego trybu nabycia nieruchomości ze strony właścicieli nieruchomości gruntowych, przedsiębiorcom przysługują instrumenty cywilnoprawne (np. roszczenia o wykup, o ustanowienie ograniczonych praw rzeczowych, o zawarcie umów dzierżawy - art. 18 i 19 p.g.g.) i instrumenty administracyjno-prawne (możliwość złożenia wniosku do właściwego starosty o wydanie decyzji o ograniczeniu sposobu korzystania z nieruchomości gruntowych na podstawie art. 125 u.g.n. ${ }^{67}$. Celowość wykupu, podobnie jak celowość jedynie ograniczenia prawa własności, jeżeli właściciel nieruchomości i przedsiębiorca nie dojdą do konsensu dobrowolnie, zostanie zbadana przez sąd w trakcie rozstrzygania sporu zainicjowanego przez przedsiębiorcę.

Wszczęcie postępowania należy poprzedzić rokowaniami z właścicielem lub użytkownikiem wieczystym, zmierzającymi do udzielenia przez niego zezwolenia na poszukiwanie, rozpoznawanie i wydobywanie kopalin objętych własnością górniczą. Rokowania powinny zostać potwierdzone na piśmie, ponieważ składając wniosek o ograniczenie sposobu korzystania z nieruchomości, trzeba je udokumentować. Jeżeli właściciel lub użytkownik wieczysty odmawia podjęcia rokowań, udokumentować należy próbę ich podjęcia oraz - o ile to możliwe - odmowę uprawnionego ${ }^{68}$.

65 J. Górski (op. cit., s. 14) przypuszcza, że celem wprowadzenia takiej regulacji jest wykluczenie możliwości niezgodnego z celem ustawy wykorzystywania tego przepisu przez przedsiębiorców wydobywających kopaliny metodą odkrywkową (art. 18 ust. 2).

66 R. Mikosz, op. cit., s. 105-121.

67 J. Górski, op. cit., s. 13.

68 P. Połczyński, op. cit. 
Ograniczenie sposobu korzystania z nieruchomości może nastąpić wyłącznie na rzecz podmiotu mającego status przedsiębiorcy. Musi on legitymować się koncesją na poszukiwanie, rozpoznawanie lub wydobywanie kopalin stanowiących własność górniczą ${ }^{69}$. Aby wywłaszczenie było dopuszczalne, nieruchomość musi być dla zakładu górniczego niezbędna pod względem technicznym, np. jej własność musi być konieczna w celu połączenia dwóch części zakładu górniczego $^{70}$. Co istotne, w orzecznictwie przyjęto, że ekonomiczna efektywność przedsięwzięcia nie jest czynnikiem wystarczającym. I tak np. chęć utrzymania mocy produkcyjnej zakładu jest przesłanką o charakterze ekonomicznym i nie może być podstawą wywłaszczenia.

Uprawnienie z art. 19 p.g.g. ma charakter roszczenia - indywidualnie oznaczona osoba może żądać od innego podmiotu spełnienia świadczenia na rzecz uprawnionego. Skuteczność roszczenia zależy od spełnienia wskazanej w przepisie przesłanki - wykup dotyczy jedynie nieruchomości położonej w całości bądź w części na obszarze górniczym. Ustawodawca nie ogranicza przepisu tylko do nieruchomości gruntowych, więc za właściwy należy uznać pogląd, który rozszerza zastosowanie komentowanego artykułu także na nieruchomości lokalowe lub budynki wzniesione przez użytkownika wieczystego oraz na inne nieruchomości ${ }^{71}$. Podkreślić trzeba, że uprawnienie regulowane przez art. 19 p.g.g. nie ma charakteru administracyjnoprawnego, w szczególności nie jest administracyjnoprawnym uprawnieniem wywłaszczenia prawa własności nieruchomości. Jest to instytucja prawa cywilnego, zbliżona nieco w swej treści do praw określonych np. w art. $231 \S 1$ i 2 k.c. $^{72}$

Regulacje prawa geologicznego i górniczego, dające możliwość wywłaszczania właścicieli nieruchomości, mimo że mogą wydawać się kontrowersyjne, nie mogą być uznane za niekonstytucyjne. Co więcej, w piśmiennictwie instytucję wywłaszczenia ocenia się pozytywnie i traktuje się ją jako niezbędny element sfery dominium państwa oraz wyjątek od zasady nienaruszalności prawa własności. Warto podkreślić, że również właściciele nieruchomości mogą żądać od przedsiębiorców wykupu nieruchomości, ustanowienia dzierżawy czy ograniczonego prawa rzeczowego w sytuacji, jeżeli działalność wydobywcza wpływa niekorzystnie na ich własność. W efekcie zarówno przedsiębiorca, jak i właściciel

${ }^{69}$ Ibidem. Uprawnienie przysługuje jedynie przedsiębiorcy, który uzyskał koncesję, tzn. że decyzja administracyjna jest ostateczna i prawomocna. Dodatkowo roszczenie może być dochodzone jedynie w okresie po uzyskaniu koncesji, a przed rozpoczęciem działalności. Tak: B. Rakoczy, Art. 19, [w:] Prawo geologiczne i górnicze. Komentarz, red. B. Rakoczy, Warszawa 2015, s. 113. Podobnie: H. Schwarz, op. cit., s. 162.

70 S. Dziubicki, op. cit.

71 Chodzi np. o własność budynków przysługujących spółdzielni rolniczej na podstawie art. $272 \S 2$ k.c., z uwzględnieniem specyfiki praw związanych. Zob. H. Schwarz, op. cit., s. 162.

72 Ibidem. 
nieruchomości mają w świetle obecnych regulacji możliwość wystąpienia z roszczeniem o wywłaszczenie za odszkodowaniem, o ustanowienie ograniczonego prawa rzeczowego (też za odszkodowaniem) oraz o ustanowienie odpłatnej dzierżawy. Ponadto przedsiębiorca dysponuje możliwością administracyjno-prawnego (przepisy u.g.n.) ograniczenia korzystania z nieruchomości gruntowej, a właściciel - w sytuacji, w której jest to dla niego nadmiernie uciążliwe - może wystąpić z roszczeniem o wykup nieruchomości. Trudno zatem mówić, że aktualne regulacje uprzywilejowują tylko jedną ze stron umowy ${ }^{73}$.

Konstrukcja umożliwiająca przedsiębiorcom przymusowy wykup nieruchomości najprawdopodobniej nie będzie powszechnie stosowana. Jednakże, gdy do tego dojdzie, właściciele nieruchomości będą podlegali ochronie sądowej, a nieruchomość zostanie wyceniona przez biegłego. Przedsiębiorcy prowadzący działalność wydobywczą zyskują możliwość wykupu nieruchomości w sytuacji, kiedy spór z właścicielem nieruchomości stałby się trudny do rozwiązania na drodze polubownej.

\section{BIBLIOGRAFIA}

Bagińska E., Parchomiuk L., Konstytucyjne podstawy odpowiedzialności odszkodowawczej z tytułu szkód wyrządzonych zgodnym z prawem działaniem administracji publicznej, [w:] System Prawa Administracyjnego, t. 12: Konstytucja Rzeczypospolitej Polskiej, red. R. Hauser, Warszawa 2010.

Banasiński C., [w:] Prawo gospodarcze, red. H. Gronkiewicz-Waltz, M. Wierzbowski, Warszawa 2009.

Banaszak B., Prawo konstytucyjne, Warszawa 2010.

Bosek L., Konstytucyjna formuła odpowiedzialności odszkodowawczej administracji publicznej, [w:] System Prawa Administracyjnego, t. 2: Konstytucyjne podstawy funkcjonowania administracji publicznej, red. R. Hauser, Z. Niewiadomski, A. Wróbel, Warszawa 2012.

Czuba S., Cywilnoprawna problematyka wywłaszczenia, Warszawa 1980.

Dybowski T., Ochrona własności w polskim prawie cywilnym (rei vindicatio - actio negatoria), Warszawa 1969.

Dziubicki S., Czy Polaków czekaja wywłaszczenia? Prawo geologiczne i górnicze a prawo użytkowania gruntu, http://infolupki.pgi.gov.pl/pl/prawo-koncesje/czy-polakow-czekajawywlaszczenia-prawo-geologiczne-gornicze-prawo-do-uzytkowania [dostęp: 06.02.2017].

Garlicki L., Artykut 21, [w:] Konstytucja Rzeczpospolitej Polskiej. Komentarz, red. L. Garlicki, t. 3, Warszawa 2003.

Gonet M., Wywłaszczanie nieruchomości w rozumieniu ustawy o gospodarce nieruchomościami, „Nieruchomości” 2012, nr 12.

Górski J., Nowe Prawo geologiczne i górnicze a sytuacja prawna nieruchomości, „Nieruchomości” 2012, $\mathrm{nr} 7$.

Hetko A., Dekret warszawski - wybrane zagadnienia systemowe, Warszawa 2012.

Jarosz-Żukowska S., Konstytucyjna zasada ochrony własności, Kraków 2003.

Jarosz-Żukowska S., Spory wokót pojęcia wywłaszczenia w ujęciu Konstytucji RP, „Państwo i Prawo" 2001, z. 1.

73 S. Dziubicki, op. cit. 
Karpiuk M., Instytucja wywłaszczenia nieruchomości, Warszawa 2015.

Mikosz R., Stosunek ustawy o gospodarce nieruchomościami do prawa geologicznego i górniczego (zagadnienia wybrane), „Rejent” 1998, nr 12.

Nakielska I., Prawo do własności w świetle Europejskiej Konwencji Praw Człowieka, Gdańsk 2002.

Panejko J., [w:] Polskie prawo administracyjne w zarysie, red. K.W. Kumaniecki, B. Wasiutyński, J. Panejko, Kraków 1930.

Parchomiuk J., Odpowiedzialność odszkodowawcza za legalne działania administracji publicznej, Warszawa 2007.

Połczyński P., Ograniczenie korzystania z nieruchomości poprzez zezwolenie na poszukiwanie lub wydobywanie kopalin. Komentarz do art. 125 ustawy o gospodarce nieruchomościami, Legalis.

Postanowienie TK z dnia 17 grudnia 2009 r., U 6/08, OTK-A 2009, nr 11, poz. 178.

Protokół nr 1 do EKPC z dnia 20 marca 1952 r. (Dz.U. z 1995 r., nr 36, poz. 175 ze zm.).

Rakoczy B., Art. 19, [w:] Prawo geologiczne i górnicze. Komentarz, red. B. Rakoczy, Warszawa 2015.

Schwarz H., Prawo geologiczne i górnicze. Komentarz, t. 1, Wrocław 2012.

Suwaj P.J., Konflikt interesów w administracji publicznej, Warszawa 2009.

Szalewska M., Wywtaszczenie nieruchomości, Torun 2005.

Uchwała NSA z dnia 20 maja 2010 r., I OPS 14/09, ONSAiWSA 2010, nr 4, poz. 55.

Ustawa z dnia 17 maja 1989 r. - Prawo geodezyjne i kartograficzne (Dz.U. z 1999 r., nr 30, poz. $163)$.

Ustawa z dnia 4 lutego 1994 r. - Prawo geologiczne i górnicze (t.j. Dz.U. z 2005 r., nr 228, poz. 1947 ze zm.).

Ustawa z dnia 2 kwietnia 1997 r. - Konstytucja Rzeczypospolitej Polskiej (Dz.U. nr 78, poz. 483 z późn. zm.).

Ustawa z dnia 21 sierpnia 1997 r. o gospodarce nieruchomościami (Dz.U. z 2010 r., nr 102, poz. $651 \mathrm{ze} \mathrm{zm}$.).

Ustawa z dnia 3 lipca 2002 r. - Prawo lotnicze (Dz.U. z 2002 r., nr 130, poz. 1112).

Ustawa z dnia 28 marca 2003 r. o transporcie kolejowym (Dz.U. z 2003 r., nr 86, poz. 789).

Ustawa z dnia 10 kwietnia 2003 r. o szczególnych zasadach przygotowania i realizacji inwestycji w zakresie dróg publicznych (Dz.U. nr 80, poz. 721 ze zm.).

Ustawa z dnia 23 lipca 2003 r. o ochronie zabytków (Dz.U. z 2003 r., nr 162, poz. 1568).

Ustawa z dnia 9 czerwca 2011 r. - Prawo geologiczne i górnicze (Dz.U. z 2011 r., nr 163, poz. 981).

Wojtyczek K., Granice ingerencji ustawodawczej w sferę praw człowieka w Konstytucji RP, Warszawa 1999.

Wojtyczek K., Zasada proporcjonalności, [w:] Prawa i wolności obywatelskie w Konstytucji RP, red. B. Banaszak, A. Preisner, Warszawa 2002.

Wolanin M., Wywłaszczenie jako prawny instrument powiększania publicznej własności nieruchomości, cz. I, „Nieruchomości” 2009, nr 7.

Woś T., Wywłaszczanie nieruchomości i ich zwrot, Warszawa 2011.

Wyrok TK z dnia 19 marca 1990 r., K 2/90, OTK 1990, nr 1, poz. 3.

Wyrok TK z dnia 12 stycznia 1999 r., P 2/98, OTK 1999, nr 1, poz. 2.

Wyrok TK z dnia 11 maja 1999 r., K 13/98, OTK 1999, nr 4, poz. 74.

Wyrok TK z dnia 25 maja 1999 r., SK 9/98, OTK 1999, nr 4, poz. 78.

Wyrok TK z dnia 12 stycznia 2000 r., P 11/98, OTK 2000, nr 1, poz. 3.

Wyrok TK z dnia 14 marca 2000 r., P 5/99, OTK 2000, nr 2, poz. 60.

Wyrok TK z dnia 21 marca 2000 r., K 14/99, OTK 2000, nr 2, poz. 61.

Wyrok TK z dnia 18 kwietnia 2000 r., K 23/99, OTK 2000, nr 3, poz. 89.

Wyrok TK z dnia 10 października 2000 r., P 8/99, OTK 2000, nr 6, poz. 190.

Wyrok TK z dnia 30 stycznia 2001 r., K 17/00, OTK 2001, nr 1, poz. 4. 
Wyrok TK z dnia 7 lutego 2001 r., K 27/00, OTK 2001, nr 2, poz. 29.

Wyrok TK z dnia 4 kwietnia 2001 r., K 11/00, OTK 2001, nr 3, poz. 54.

Wyrok TK z dnia 26 marca 2002 r., SK 2/01, OTK-A 2002, nr 2, poz. 15.

Wyrok TK z dnia 16 kwietnia 2002 r., SK 23/01, OTK-A 2002, nr 3, poz. 26.

Wyrok TK z dnia 20 listopada 2002 r., K 41/02, OTK-A 2002, nr 6, poz. 83.

Wyrok TK z dnia 24 marca 2003 r., P 14/01, OTK-A 2003, nr 3, poz. 22.

Wyrok TK z dnia 4 maja 2004 r., K 8/03, OTK-A 2004, nr 5, poz. 37.

Wyrok TK z dnia 30 listopada 2004 r., SK 31/04, OTK-A 2004, nr 10, poz. 110.

Wyrok TK z dnia 14 marca 2005 r., K 35/04, OTK-A 2005, nr 3, poz. 23.

Wyrok TK z dnia 3 kwietnia 2008 r., K 6/05, OTK-A 2008, nr 3, poz. 41.

Wyrok TK z dnia 18 września 2008 r., K 7/07, OTK-A 2008, nr 7, poz. 123.

Wyrok TK z dnia 9 grudnia 2008 r., K 61/07, OTK-A 2008, nr 10, poz. 174.

Wyrok TK z dnia 17 grudnia 2008 r., P 16/08, OTK-A 2008, nr 10, poz. 181.

Wyrok TK z dnia 6 stycznia 2009 r., SK 22/06, OTK-A 2009, nr 1, poz. 1.

Wyrok TK z dnia 24 lutego 2010 r., K 6/09, OTK-A 2010, nr 2, poz. 15.

Wyrok TK z dnia 10 października 2000 r., P 8/99, OTK 2000, nr 6, poz. 190.

Wyrok TK z dnia 20 kwietnia 2011 r., KP 7/09, OTK-A 2011, nr 3, poz. 26.

Wyrok TK z dnia 13 grudnia 2012 r., P 12/11, OTK-A 2012, nr 11, poz. 135.

Wyrok TK z dnia 16 czerwca 2015 r., K 25/12, OTK-A 2015, nr 6, poz. 82.

Wyrok WSA w Warszawie z dnia 12 maja 2005 r., I SA 2250/03, niepubl.

Wyrok WSA w Warszawie z dnia 9 stycznia 2008 r., I SA/Wa 840/2007, LEX nr 459779.

Wyrzykowski M., Granice praw i wolności-granice władzy, [w:] Obywatel-jego wolności i prawa, oprac. B. Radzikowska, Warszawa 1998.

Zaradkiewicz K., Artykuł 21, [w:] Konstytucja RP, t. 1: Komentarz do art. 1-86, red. M. Safjan, L. Bosek, Warszawa 2016.

Zaradkiewicz K., Instytucjonalizacja wolności majątkowej. Koncepcja prawa podstawowego własności i jej urzeczywistnienie w prawie prywatnym, ,Studia i Materiały Trybunału Konstytucyjnego" 2013, t. 45.

Zdyb M., Wywłaszczenia. Komentarz. Orzecznictwo, Lublin 1993.

Zimmermann M., Polskie prawo wywłaszczeniowe, Lwów 1939.

Zoll F., [w:] Prawo cywilne w zarysie. Prawo rzeczowe, red. F. Zoll, A. Szpunar, t. 2, z. 1, Kraków 1947.

\section{SUMMARY}

Art. 21 of the Polish Constitution respects the freedom of ownership, understood as the protected sphere with regard to possess and dispose the property. It forbids the unlawful interference in the individual's legal status made by the public authorities or any other participant of legal transactions. However, the guarantee of sustainability does not imply inviolability of the property law. Under the constitutional provisions it is concluded that property is a right permitted insofar as it is necessary to ensure the essential public objectives. The expropriation is a legal institution, which enables obtaining rights in real estate recognized for other individuals, if it might be considered necessary to implement public objectives; and through just right compensation. The legal solution, created by the art. 19 of Geological and Mining Law enabling the entrepreneurs to compulsorily buy-out the real estate seems to be dubious from the constitutional point of view. The specificity of legal instruments allowing being deprived of the right or limitation of the right to real estate for the needs of exploration and exploitation of minerals is that such de facto expropriation takes place on favor of private entrepreneurs. The question arises, how much business activity consisting in mining can be considered a public objective. 
Keywords: expropriation; limitation of ownership; exploration and exploitation of minerals; buy-out; right compensation

\section{STRESZCZENIE}

Art. 21 Konstytucji RP chroni wolność własności (wolność majątkową) rozumianą jako sfera chroniona w zakresie dysponowania przedmiotami majątkowymi. Zakazuje ponadto bezprawnej ingerencji w sferę indywidualnego statusu prawnego organom władzy publicznej i wszystkim innym uczestnikom obrotu prawnego. Gwarancja trwałości nie oznacza jednak nienaruszalności prawa majątkowego. W świetle regulacji konstytucyjnych należy stwierdzić, że własność jest prawem dozwolonym na tyle, na ile nie jest konieczne jej ograniczenie lub odebranie dla ochrony interesów społeczeństwa postrzeganych jako interes publiczny. Wywłaszczenie nieruchomości jest instytucją prawną, której istnienie umożliwia państwu pozyskiwanie praw przysługujących do nieruchomości innym podmiotom, jeżeli jest to konieczne dla wykonania istotnych celów publicznych i za słusznym odszkodowaniem. Rozwiązanie prawne przyjęte w art. 19 ustawy - Prawo geologiczne i górnicze, umożliwiające przedsiębiorcom przymusowy wykup nieruchomości, może wydawać się wątpliwe z konstytucyjnego punktu widzenia. Specyfika instrumentów prawnych pozwalających na pozbawianie prawa lub ograniczanie prawa własności nieruchomości gruntowych na potrzeby poszukiwania i rozpoznawania oraz wydobywania kopalin polega na tym, że takie de facto wywłaszczenie następuje na rzecz przedsiębiorców prywatnych. Pojawia się pytanie, na ile działalność gospodarczą, polegającą na wydobyciu kopalin, można uznać za cel publiczny.

Słowa kluczowe: wywłaszczenie; ograniczenie prawa własności; wydobycie kopalin; prawo wykupu; słuszne odszkodowanie 